\title{
Hindu-Muslim relations in Kashmir: A critical evaluation
}

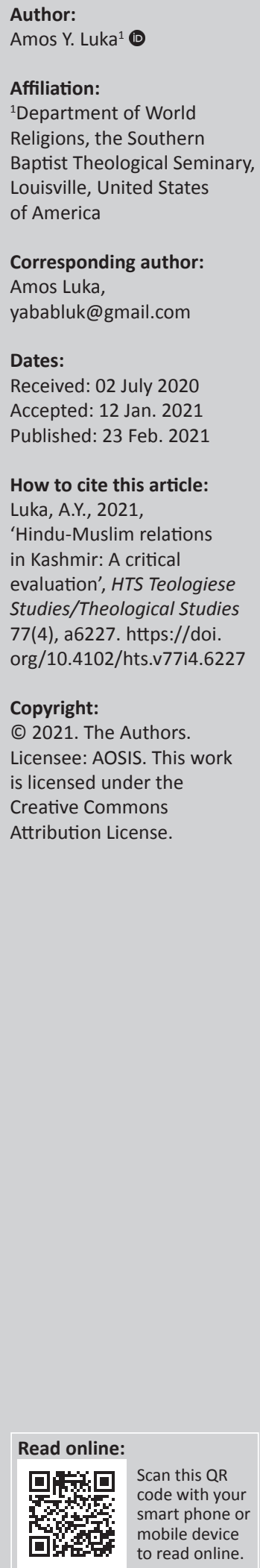

India was under British colonial rule for a good number of years with her plural ethno-religious background and identity, which was to become the basis of an unending conflict. Several precolonial and post-colonial conditioning antecedents have been marshalled to buttress the premise leading to the conclusion that the British colonial era laid the time bomb along ethno-religious contours which exploded in 1947 thereby giving rise to the balkanisation of India into two separate states, that is India and Pakistan. Two major religious groups that is Hindus and Muslims became the gladiators in India's partition. The Kashmir region of India, a town of religious confluence, has a history of conflicts that is perceived by different people as politico-religious and socio-economic. This article focuses on religion as a core tenet of every cultural worldview and its significance to both Hindus and Muslims, and how it has become the progressively vital central marker of identity and a smouldering keg of gun powder for conflict in Kashmir. Furthermore, this article contends that religion plays a key role in the conflict between Hindus and Muslims in Kashmir because of its significance and influence on both religions. India that is known as a mother to various religions cannot relegate the primary role of religion in their political and socioeconomic affairs. Therefore, it is right to acknowledge politico-religious and socio-economic factors in the Hindu-Muslim conflict in the state of Kashmir. And, it will not be wrong to affirm that religion plays a key role in the conflict between Hindus and Muslims in Kashmir.

Contribution: The article is a contribution in religious issues in India. It reveals how political power and sociopolitical antecedents are mostly recognised by religious scholars and historians as the reason for the fracas between Hindus and Muslims. It explains the influence and implication of religion in the Hindu-Muslim relations in Kashmir region.

Keywords: Hindus; Muslims; religion; fundamentalism; Kashmir; India; Hindu-Muslim; nationalism; communalism.

India was under British colonial rule for many years. The nation has an ethno-religious background and identity that becomes the basis of an unending conflict. There were several conditioning antecedents before and after the colonial era that marshalled the premise leading to the conclusion that the British colonial era laid the time bomb along ethno-religious contours which exploded in 1947 thereby giving rise to the balkanisation of India into two separate states, that is India and Pakistan. Two religious groups that is Hindus and Muslims became the major opposing parties in India's partition theatre of conflict (Pillalamarri 2019). ${ }^{1}$ Millions of people died in the conflict that ensued and the riots progressively exploded along religious stripes in a country where around $13.4 \%$ of the population is Muslim, with an $80.5 \%$ Hindu majority. ${ }^{2}$ The relationship became more strained in the 1960s and 1970s and reached its peak in 1992, when a conservative Hindu mob under the influence of the ruling Hindu nationalist, Bharatiya Janata Party (BJP) shattered the Babri Mosque in Ayodhya (Ellis-Peterson 2020). ${ }^{3}$

Putting this existential context under closer examination, Talbot's (1999:692-722) sharp view regarding one of the pivotal roots that spurred frequent eruptions of conflict becomes critically necessary. She says:

1.Pillalamarri reflects the common denominator of opinions of various schools of thoughts constitutive of the academia and popular historical residue that seek to trace the causative factors behind Hindus and Muslims conflict in South Asia. His view hinges on the presupposed colonial rule and policies of the British, and Western influences on the postcolonial Hindu-Muslims religious interface particularly in the Kashmir region.

2.According to the Office of the Registrar \& Census Commissioner (n.d.), India has $80.5 \%$ Hindus, $13.4 \%$ Muslims, $2.3 \%$ Christians, $1.9 \%$ Sikhs, $0.8 \%$ Buddhists, $0.4 \%$ Jains, $0.6 \%$ others and $0.1 \%$ religion not stated. See https://censusindia.gov.in/Census_And_You/religion.aspx.

3.Patterson (2013:4) explains that the impact of the 1947 partition resulted in a crises between India and Pakistan along the border area of Kashmir. The core reason for the conflict is nationalism, but religion is a key player. Thursby (1975:1) gleaned through the 1923-1928 British Kashmir. The core reason for the conflict is nationalism, but religion is a key player. Thursby $(1975: 1)$ gleaned through the 1923-1928 British
rule and discovered controversy, conflict and communal movement as the three features of the darker side of the Hindu-Muslim relations in the Northern region of India. Jones (1968:39-54) defines communalism as 'a consciously-shared religious heritage which becomes the dominant form of identity for a given segment of society'. The definition provides the perspective of 'nationalism'. Wilsey (2015:116) succinctly describes 'nationalism' as being tribalistic, triumphalist, religious (idolatrous), exclusivist and a contravener of justice. 
The focal point of nationalist sentiment is the most visible symbol of Hinduism, its temples. As many as 60000 Hindu temples are said to have been torn down by Muslim rulers, and mosques built on 3000 of those temples' foundations. (Talbot 1999:692-722)

The Kashmir region of India has a long recorded history of incongruities and conflicts that are perceived by different people as politico-religious and socio-economical. The Kashmir region has about three major religions, with Islam being the dominant religion in the Kashmir valley. In addition to that, Hinduism and Buddhism also constitute a part of the religions in Kashmir. According to Jammu \& Kashmir Tourism Development Corporation (n.d.), in 'the 2011 census, Islam is practiced by about $68.3 \%$ of the state population; whilst $28.4 \%$ follow Hinduism and small minorities follow Sikhism (1.9\%), Buddhism (0.9\%) and Christianity $(0.3 \%)^{\prime}$. Statistically, the Hindu-Muslim population in India indicates the two religions as being predominant in the nation and is projected to be the most populous in the entire world. The Islamic religious demography of India is projected to be approximately 311 million Muslims in 2050 (11\% worldwide), which will be the largest population of Muslims in the world against Indonesia where presently it is the largest. This suggests that Muslims are expected to grow faster compared to Hindus because of the youngest median age and the highest fertility rates amongst major religious groups in India. It reveals the likelihood that the Muslim community will multiply faster than the Hindu community at $14.4 \%$ in 2010 to $18.4 \%$ in 2050 (Hackett 2015).

After considering the above complex ethno-religious context of the Kashmir region, the article will argue that religion plays a key role in the conflict between Hindus and Muslims in Kashmir. First, it will explore the history of Hindu-Muslim relations in Kashmir. Second, it will acknowledge the politico-religious and socio-economic influences on the Hindu-Muslim relations. However, it will also focus on religion as a core tenet of every cultural worldview and its significance to both Hindus and Muslims, and how it becomes the progressively vital central marker of identity and a smouldering keg of gunpowder for conflict in Kashmir (Patterson 2013:4). Lastly, the article will reflect the use of secondary sources to explore the history of Kashmir and critically evaluate the significance and influence of religion in Hindu-Muslim relations.

\section{An overview of the History of Kashmir}

Historically, the pre-Mahabharata days marked the beginning of the making of Kashmir, a place that became the centre of both civilisation and Indo-Vedic culture. According to the oldest record, Neel, the son of Kashyap Rishi who was believed to be a worshipper of a snake was the first ruler of Kashmir. At that time, the Nagas were acknowledged as the earliest inhabitants and were portrayed as serpent deities. They were worshipped by the
Brahmin inhabitants but had to subdue the Yakshas and Pisachas for a peaceful co-habitation in Kashmir. The prehistoric past reveals the diverse ethnicity of the Kashmiri society and the way the context was shaped by the mixed integration and assimilation of their identities which are commemorated in Nilmat Puran, a sixth and seventh century Sanskrit text that provides creation myth for Kashmir (Misri \& Misri 2016:26-27). Therefore, the history is such that the Aryans went to the region after the rise and fall of others who had been initially there. Later, Kashmir was introduced to Vedic religion followed by Buddhism. Younghusband (1909) alludes:

The people that build the ancient temples of Kashmir must have been religious, for the remains are all of the temples or sacred emblems, and not of palaces, commercial offices, or hotels. (p. 99)

A recent documentary reveals archaeological facts about the history of Kashmir linked to the period of Alexander the Great, the Sultans and the Sikhs with others in between, to the contemporary times (Malik 2018). Succinctly, the historical chronology of Kashmir began with the Hindu period (3067-1339 BCE) followed by the Muslim period (1339 BCE - AD 1586), Mughal period (1586-1752), Afghan period (1752-1819), Sikh rule (1819-1846), Dogra rule (1846-1947) and the post-accession era (1947 to the present) (Misri \& Misri 2016:26). ${ }^{4}$

Indian independence (1947) from British rule created a divide with Islamic Pakistan and a secular but majority Hindu India and it has been the issue of disagreement between India and Pakistan (eds. Augustyn et al. 2019). The Kashmir region was left alone, it was neither a part of India nor of Pakistan, causing Maharaja Hari Singh to dither and led to the invasion by the Pakistani army until Kashmir acceded to India (Metcalf \& Metcalf 2006:224). A documentary reveals that tension, disagreements, protests and conflicts in the region of Kashmir emanated from the communal, religious and political struggles during the leaderships of Maharaja Hari Singh, Major William Brown and Sheikh Mohammed Abdullah (Malik 2018). ${ }^{5}$ The transition of power in 1947 led to a violence that marred the Kashmir region along religious lines and smacked of sectarianism. It is illustrated in the forceful migration of a large crowd of Hindus who left their homes in Pakistan for India just as a large crowd of Muslims migrated in the opposite direction (eds. Gold et al. 2019). The region of Kashmir experienced years of conquest in the entire subcontinent which resulted in the division of the subcontinent between the Muslim state of Pakistan and a secular republic of India with the Hindus as the majority (Nielsen 1993:112).

4.Malik (2018) notes that the historical chronology differs slightly in dates and names. $\mathrm{He}$ begins with Alexander the Great $(326 \mathrm{BC})$ followed by the Sultan dynasty (AD 1339-1561), the Mughal empire (AD 1586-1751), the Durani empire (AD 1747-1819), the Sikh empire (AD 1819-1846). It seems best to see the two chronological arrangements and the names that are interchangeably used by chronological arrangements and the names that are interchangeably used by scholars as similar. Gold et al. (2014) note that Greeks and Persians who were the early residents of the Indus Valley mentioned Hindu as the language spoken by the inhabitants. This creates the impression that Misri's idea of Hindu period refers to
the time of Alexander the Great or Greeks and Persians.

5.The documentary gives the details of the historical fact on the successional leadership and their conflicts from 1947 onward. 


\section{Hindu history}

Religion in India was commonly seen as the Aryan religion that was introduced by invaders from the north (Eliot 1962:15). ${ }^{6}$ The textual history of the religion of India elucidates that the Aryans, or Aryas were nomadic pastoralists who came from south-central Russia into the subcontinent and presented themselves as the noble ones, even though they were known as horse riders and inventors of chariots and weapons from copper and bronze (Davis 1995:7). Kashmir has a religion from its remote date that was acknowledged as Hindu because of certain features that were similar to Ophite, or Snake worship, which has been a part of Hindu rituals including that of the Nagas in the pantheon (Wilson 1960:83). There seems to be a progressive evolution of faith which is traced with time as illustrated by the different forms of religions such as Aryan, Vedic, Brahmanism and others. These forms of religion had a connection with the concept of superior gods, religious cults and sacred places which all appear to be very similar. This reveals the primitive foundation of Hinduism in its Indo-European origin even though the content was substantially indigenous with modifications due to the influences of invading tribes or nations. Noticeably, the Aryans invaded in the second millennium and introduced their organised religious beliefs that outlasted in classical Hinduism after multiple modifications (Renou 1961:16). ${ }^{7}$ The ancient Greeks formulated the name for those living around the Indus River or valley as Hindus, and it was later adopted by Persians and used by the British. Thus, the name did not naturally start from within, but was given and used by those whose knowledge of the Indian religion was shallow (Frost 2004:139). This makes sense and illustrates the progressive evolution that separate the original Iranian religion (preZoroastrian) and what resulted as the Vedic religion in the north-western India (Renou 1961:16-17).

The documentary on Kashmir traced the idea of 'Hindu' back to the time of sage Kashyapa when the lake that covered the valley at Varaha-Mula or Baramulla was drained to provide a habitation for the people of the Kashmir region. The region from the beginning was known as the seat of Shaivism with a monument dedicated to Shiva, which was visited by the adherents for the purpose of pilgrimage (Malik 2018). Shaivism was later discovered to be a form of Hinduism that was more vernacular and less Sanskritic. It derived from a different corpus of sacred text which led to Agama-centric Tamil Hinduism with a different gravitational force (Young 2014:49-50). ${ }^{8}$ Gavin Flood (2003:3) sheds light on Hindu with specific reference to Kashmir to reveal the reason for the name Hindu. He argues that the term was used in the fifteenth century Kashmir by Saiva historian Srivara to make

6.Eliot seems to argue that there is no information comparable to the old Dravidians Werner (1994:60) notes that the Dravidian refers to non-Aryan languages or peoples of India who were considered to be of ancient Mediterranean origins. This seems to give an idea about origin of religion in India as well as Kashmir.

7.Renou notes the possibility that Hinduism assimilated some pre-Aryan or non-Aryan institutions that were gotten from local cults and primitive Indian data that undergo modification.

8.Augustyn et al. (2019) note that Shaivism is an organized worship. Shiva, an Indian god, is a form of modern Hinduism. a distinction between Muslims and non-Muslims, and it was used in Sanskrit and Bengali Vaisnava sources to denote non'Yavanas', or Muslims in the sixteenth century. However, it was discovered that Hinduism originated around the sixth and the fourth centuries B.C.; towards the end of the original Vedic period and at a time when the essence of the old Vedic religion got lost. The religious manifestation of Hinduism that was chosen did not expose any trace of dissection in the primordial liturgical patterns (Renou 1961:18-19). This suggests that Brahmanism, known as the oldest form of learned Hinduism; Vedism, known as the primordial form of Hinduism and Shaivism that is known as the modern form of Hinduism, were all part of the process of the religious evolution in the Kashmir region. Frost (2004:139) asserts in his well-articulated piece: A History of Christian, Jewish, Hindu, Buddhist, and Muslim Perspective on War and Peace, that as a form of Indian nationalism in the late nineteenth century, Hinduism is reflected as a holistic religious movement that incorporates Vishnu, Siva and Shakti along with countless other deities, and includes present-day minorities like Sikhs, Jains and Buddhists.

Historically, the successions of different eras in the Kashmir region had a great influence on the religious life and activities of the people. It became obvious that religion was used unequivocally to support the nationalist movement, to become antagonistic and replace the colonial regimes and those perceived as invaders. This was aimed at reawakening the pride of India and its religious heritage (Smith 1971:96). So, the objective of the Hindus was to restore their statues of gods and temples that were destroyed by Muslims and invaders, and to develop a unified social system of Hinduism that is reflected in a broad-based, indigenous and nationalist movement with a new ethos (Nielsen 1993:112-113) even though it is polytheistic in its formation. Consequently, it is averred that Hinduism has ever since continued as the national faith of Kashmir (Wilson 1960:85).

\section{Muslim history}

By the time Lalitadiya (699-736 C.E.), a famous indigenous king who was a contemporary of Charlemagne, became the ruler of Kashmir, Muhammad had been dead a 100 years without his religious movement having yet reached India (Younghusband 1909:87). This period was characterised by restructuring, successions by weak rulers and foreign expeditions to revive the traditions within the regions of Kashmir and India (Younghusband 1909:88). The famous Mahmud of Ghazni who forcefully introduced Muhammadanism in upper India, attempted to invade Kashmir in AD 1015, but was unsuccessful (Younghusband 1909:89-90). Centuries later, there were great advances in the kingdom of the Punjab and the establishment of the Mohammedan dynasty led by Shah Mir around AD 13391341. He was 'considered the first, true Mussulman king of Kashmir' (Wakefield 1879:77-78). This resulted in the influx of foreign adventurers from Central Asia and led to the conquest of the region by foreign invaders, with Kashmir being made a part of the territories of the great emperor 
Akbar in AD 1586. The cruel oppression of the Afghan rule in AD 1750, made many people convert to Islam: one-tenth of the Kashmiris were converted to Muhammadanism. In AD 1819 when the oppression became unbearable, people had no other option but to flee to the Sikh ruler of Punjab, known as Ranjit Singh (Younghusband 1909:92-94). A documentary on the history of Kashmir reveals the form of Islam that evolved and was probably practiced in the preceding narrative. It records that during the Sultan dynasty (AD 1339-1561) Sufism was introduced by Sheikh Nund Rishi, and his tomb remains a place of pilgrimage (Malik 2018). It seems Sufism appealed to the people because of the ascetic and mystical tendencies it projected. A particular shrine dedicated to multiple Muslim saints marks the locations of some local, Hindu, cultic ritual that was performed on certain spots before the advent of Islam in Kashmir. One such Muslim saint was a Hindu ascetic, who bore the name of Bhuma Sadhi and was a pious Hindu monarch. He later became a Muhammadan saint and merged the local faith with the new one (Stein 1900:249). It was influenced by Hellenistic, Gnostic, Christian and Indian mysticism: its Vedantic roots influenced the Hindu orthodoxy and brought about a spiritual movement in the Hindu population (Werner 1994:145).

In the wake of Buddhism, by the ninth century, the influence of Islam was weakening and losing relevance, with Vaishnavism and Shaivism gaining ground. However, the advent of Islam in Kashmir in the fourteenth century upturned the Kashmiri society with is beliefs, ideology and practices. It was at that time, when foreign adventurers and refugees were entering Kashmir that was under the reign of King Suhdev (AD 1301-1320) that Islam took over Kashmir (Misri \& Misri 2016:113). Sadr-ud-Din, earlier known as Rinchina who was denied entry to the Hindu fold by the Shaiva guru embraced Islam and became the first Muslim ruler of Kashmir. It is alleged that Shah Mir, in connivance with Bulbul Shah manipulated the conversion and establishment of Rinchina as the Muslim ruler in Kashmir (Misri \& Misri 2016:115)..$^{9}$ A man from Hamadan in Persia, known as Sayed Ali Hamadani was said to have fled from the Mughal emperor to Kashmir in AD 1395. He and his son, believed to be Sunni Muslims, initiated the process of islamisation of Kashmir during Rinchina and Shah Mir's time and instigated the intense persecution of Hindu Kashmiris. The event was described as 'a nightmare of mass massacres, holocausts, genocidal attacks, and enslavement' (Misri \& Misri 2016:117). It resulted in their converting about 37000 Hindus to Islam which earned him the reputation of being one of the greatest Islamic missionaries by the Kashmiri Muslims. It is a fact that even Sultan Qutab-din was unable to propagate Islam the way Sayed Ali Hamadani did. Sayed left for Baramulla allegedly on a pilgrimage to Mecca and mandated the Sultan to forbid non-Muslims from reconstructing and building new places of worship; possession of weapons of any kind; building houses in Muslim areas; entertaining Muslim guests in their homes recorded the conversion of Shah Mir's forefather to Islam. It seems they were originally Kshatriyas. and to wear dresses that distinguished them from Muslims (Misri \& Misri 2016:118). The legacy of Sayed Hamadani continued through Pompur, Avantipur and Khanqahs, and a mosque was built at Khanqah Maula as a memorial to him.

\section{Hindu-Muslim relations in Kashmir}

Records have shown that the relations between the Hindus and the Muslims were as old as Islam. It can be traced to a time even before Muhammad the Islamic Prophet, when Arab traders had settlements, but they had very little interest in the subcontinent and its great religious controversies. However, it was noticed that on converting to Islam, their attitudes changed because of the deep influence of the Saivite cults and Islamic influence which can be traced even in the work of Shankaracharya, the great Hindu reformer and thinker who created a persuasive system out of random speculation. It was a period of cordial relations between the Indians and the Muslims as evidenced by the settlement of several Muslim traders in some important towns in Northern India during the Hindu era (Misri \& Misri 2016:118). The Sira Puranam of the early nineteenth-century referred to Muhammad as the prophet of Islam and creates the impression that he set an excellent example for Muslim interactions by establishing hundreds of shared ritual spaces, called dargahs for Hindus and Muslims. Both Muslims and Hindus visited the shrines that were named after venerated Muslim (normally Sufi) leaders. Furthermore, the two religions were said to be hospitable to each other because of the proximity and daily interaction they had throughout the centuries; manifested in the combination of some devotional groups with shared beliefs in monotheism, whether God was called Allah, or Brahman (eds. Gold et al. 2019). All these are indications of the fusion of beliefs and practices between Hindus and Muslims, establishing the non-sectarianism that existed in northern India. It is recorded that both Hindus and Muslims had castes and sects and belonged to the Aryan race, which means that they communicated in a common language (Dogri) that has a mix of Sanskrit, Punjabi and Persians with words derived from Indo-Aryan Sanskrit. They observed common festivals, lived with tolerance and shared traditional attires that were similar (Bamzai 1994:14). The king's chronicle attests that during the time before Shah Mir of the Muhammadan dynasty (AD 1339), there was no record of a revolution of any kind and the transition from the Hindu to the Islamic rule was said to be accepted through gradual conversion and the influx of adventurers from the south and central Asia. That prepared the ground for the adoption of Islam in a Brahman context without affecting the independence and the country's administrative set-up, political and cultural conditions. This is an illustration of Hindu-Muslim relations that reflects tolerance, hospitality, community, indifference, independence, diversity and friendliness.

The Hindu-Muslim relationship was progressive in the period leading to the transition of leadership with rules that were diverse and complex in nature. Historically, there were times when the popular press in the Punjab, together with 
those in the United Provinces, promoted acrimonious Hindu-Muslim exchanges, which later became the basis of the inter-religious tensions maintained by them (Thursby 1975:4). The progressive tensions in the Kashmir region resulted in numerous sectarian violence that led to the destruction of some Hindu temples by militant Muslims (eds. Gold et al. 2019). The king's chronicle acknowledged the series of weak and nominal Sultans who ushered divisions, bitter rivalries and contests; communalism and factionalism in the territory which led to long drawn-out strife amongst the feudal families because of the rapid succession of puppet-kings that rose and fell (Stein 1900:131). The expression of communalism led to conflicts in the traditional religious observances like the festival of Bakri Id and Ram Lila. Communal riots erupted with the ritual sacrifice of the cow by Muslims during celebrations; the cow was an emblem of religious piety amongst the Hindus (Thursby 1975:4-5). This is typical of the religious tensions in Hindu-Muslim relations in Kashmir that exists to this day and is reflected in the political and socio-economic situation of the country. Although there were many interests in most Hindu-Muslim riots, but it has a primary concern that is not far away from religion or religious interest, and there was the exercise of political powers by the British, transferred to the people along the communal line (Thursby 1975:6)..$^{10}$ This seems to allude to the fact that the British rule or the imperialist policy of divide and rule was one of the reasons for Hindu-Muslim tensions. It might be perceived that the concern for power was achieved through the expression of religion in politics (Thursby 1975:7), or 'the notion of conflict ... involving religious communities, socio-religious structures, clerical institutions, and religious ideologies' (Smith 1970:144-145).

\section{Politico-religious influence}

Influenced by the British educational and political institutions, since the 1880 s there was a dark side to the dialogue that flourished in the northern part of India. With a revitalisation of interest in religion people began to question the orthodox traditions and controversialism, as reflected in the case of Arya Samaj with Islam around 1877, which brought about religious revivalism and social reform (Thursby 1975:9-10). Politically, it looks like India is always ready to divert her wealth and might to battle antagonists just to preserve the Kashmir region and the traditional Hindu religious values, which is the reason why they are willing to talk about it but not negotiate it. India seems to have underlying reasons for its refusal to negotiate the border dispute with China and Pakistan because of its perception of Kashmir and its people. Before the thirteenth century, it became obvious that the legitimation of political authority by temple Hinduism began to unfold through claims of sovereignty and ritual observance and worship of Hindu deities from Delhi and parts of South Asia. The growth of the Sufis was perceived as a political threat to the different forms of Hindu religious activities and the Hindus responded by asserting their claim on traditional values and restoring the desecrated temples (Davis 1995:37-38). The action taken by Hindu nationalists in northern India led to the formation of socio-religious and socio-political orders. It becomes evident that certain religious practices that might be perceived as religious fundamentalism can be an influential factor that instigates religious intolerance. It is this ideology of Hindu nationalism that is reflected in the new direction the development of Indian religions has taken (Davis 1995:38).

Since the 1920s there has been a gradual paradigm shift from religious pluralism to communalism and fundamentalism, along with power and politicisation. Smith (1957:172) avers that a period of communalism pervaded the affairs of India increasingly, and became like a habit-forming drug administered in doses. Religious communalism and fundamentalism mixed with the exercise of power and politics led to a series of communal tensions and riots in India just as it had been observed. Religious fundamentalism, grounded in a fiery worldview and legitimised by radical religious leaders, gods or goddesses and organised by radical disciples, led to an assortments of religious violence and hostilities with social and political overtones (Clarke 2017:2-3). Historically, as a fallout of certain controversial exercises of political power by the British in the 1920s, Indian society experienced communal controversies and riots. This led to the Gandhian non-violent movement against the British and the call for inter-communal harmony, ending the soured relationship between Hindus and Muslims. The Hindus strengthened and consolidated their community and emerged into an age of Hindu communal resurgence (1923-1928). The influence of religion and politics in the entire process of religious communalism and fundamentalism is revealed in the Gandhian Shuddhi, and Sangathan movement (Thursby 1975:6-7). ${ }^{11}$ Hindu fundamentalism that is often used as a cognate for nationalism is not focused on a global politico-religious order, but to transform India into a Hindu nation with individual expressions and social interactions related to dharma (Clarke 2017:151).

\section{Socio-economic influence}

It is obvious that the modern history of Kashmir, masterminded by Akbar's conquest, had commenced even though the conservative instinct compelled a larger portion of the people to preserve their old traditions and customs. There was a transformation of the political and economic situation of the country as a result of its political connections with the great empire and other territories (Stein 1900:131). It appears there is limited documentary evidence on the socio-economic life of the Kashmir region, even though respected Kashmiri historians like Kalhana in his Rajatarangini, and Kshemendra and Jonaraja in their work the Nilamatpurana, provided helpful information of the ancient Kashmir (Bamzai 1994:183). Historically, the Greco-Roman and

11.Thursby notes the work of Arya Samaj sannyasi, Swami Shraddhanand in the shuddhi movement of reconverting and incorporating former members into the shuddhi movement of reconverting and incorporating former members into the
main body of Hinduism. He also notes that the sangathan movement was intended for the creation of a militant image and a rebranded Hindu. 
Persian expeditions covered the region and their historians attest to the existence of an ancient city that is purported to have had its capital in Kashmir; a place known to foreigners and was considered a kingdom because the Rajdhani or palace of the Hindu king had the Shankaracharya hill as its landmark and from other evidence gleaned from artefacts in sculptured blocks, pillars and images on walls that were in all probability located there (Bamzai 1994:187). Furthermore, excavations unearthed the foundations of an old temple of stones that revealed the city to have been better than others because of its surpassing charm and beauty, revealed in its weather and vegetation (Bamzai 1994:187-188). Socially, during the Hindu rule, the city of Kashmir comprised several castes, from the ruling and the fighting to the low caste (Bamzai 1994:191). Socially, the Kashmiri Muslim men and women lived in harmony with few and sometimes inconspicuous, differences in dress, food and occupation (Wakefield 1879:252-255).

Economically, it is acknowledged that there were natural and agricultural resources in Kashmir that the foreigners craved for, which is an indication that their economy attracted foreign aggression, even though they enjoyed the protection of the mountains that provided natural fortifications (Stein 1900:132). ${ }^{12}$ From a historical point of view, the impression that was created was of a city that became the centre of attraction and commerce, comprising some outsiders of lowcaste, whose occupations were those of scavengers, nightwatchmen and boatmen, influencing the Hindus in Kashmir with their faith (Bamzai 1994:192). Kalhana, the ancient historian alluded to the possible presence of accrued precious stones in the Kashmir region and claimed that transactions in gold and silver coins took place. The Muhammadan rule as declared by the first Sultan taxed the Brahmans who refused to be converted with two palas of silver per head yearly (Stein 1989:317-318). This creates the impression that one reason for the expeditions could be socio-religious expansion and economic empowerment.

\section{Critical evaluation of the Hindu- Muslim relations in Kashmir}

It is fascinating to know that fourteenth century Kashmir was not entirely Brahmin, an indication that religious nationalism was a later invention. It is also interesting to note that the northern region of India up till the present has not been a homogenous community. It has been the centre of traditions like orthodoxy, theocracy, Bhakti, liberalism and Sufism. Therefore, religious tension was a major part of their existence, as well as conflicts of interest which is mostly legitimised as religious conflicts. More so now than ever before, all these have resulted in Hindu communalism and Muslim fundamentalism turning the northern region of India into a conflict zone for Hindus and Muslims (Engineer 1999:263). The region was known for its religious pluralism with the existence of religious sects like Tantrins, Damaras,
Bhiskshas, Bhauttas, Darads, Khashas, Nishads and others (Bamzai 1994:16). It is in this context that it may be considered the time was ripe for Christian missionaries to make inroads and for the gospel to thrive. Metzger (2012:189) in his explanation of pluralism affirms that 'There is much good that has come from affirming diversity and multiculturalism'. Metzger (2012:190) further notes the danger of tolerance in a pluralistic context because it can affect the true meaning of evangelism and can turn it to proselytising and syncretisation.

The beginning of Islam in Kashmir and northern India at first seemed like a welcome idea probably because Hindus had no option and the entire region was ruled by the Sultan dynasty (AD 1339-1561), but it became a worrisome relationship between Hindus and Muslims because competitive communalism had turned into fundamentalism. In Indian society, even though secular, religion occupied a primordial position in their politics and turned the multi-religious and multi-ethnic milieu into a disaster (Engineer 1999:269). It becomes evident that Kashmir and northern India have the competitive spirit of fundamentalism because religions seem to compete with and challenge each other to rule over and therefore shift the blame to the political, socio-economic and psychological aspects of Indian life (Clarke 2017:154-155). If religion and ethnicity have presently become the key markers in the Kashmir region, then their multiculturalism which is the mark of religious pluralism sets the platform for confrontational disagreements between Hindus and Muslims across religious lines; tied to politics, nationalism and fundamentalism (Patterson 2013:8). This creates the perception that religion is both significant and influential in the Kashmir region and India.

\section{Religious significance}

India is known to be the 'mother' of different religions and northern India had its seekers and sages like Mahavira and the Buddha, who were not interested in political power. Rather, they were driven by their desire for a higher religious truth. Northern India can be seen as a confluence of great religions, and practices of inter-religious debate and dialogue as seen in the participation of the Mughal emperor Akbar who enjoyed debating to gain a broader religious understanding (Thursby 1975:9). The Kashmir region has been known to be ruled by Hindus from the beginning, which had distinct relations with Ophite or snake worship as a part of the Hindu ritual, and the mention of Nagas in the orthodox Pantheon (Wilson 1960:83). The advent of Muslims in the Kashmir region in the fourteenth century and the synthesis of the two religious thoughts advocated by Lalleshwari and Sheikh Nur-ud-din resulted in religious tolerance as seen in the veneration of the two advocates through pilgrimage even to this day (Bamzai 1994:17). It is pertinent to understand that the history of Kashmir cannot merely be considered an academic exercise but also one of faith because of past misconceptions of those people who have been ridiculed for their secular outlook and independent behaviour by 
expansionists, political adventurers from the west and the communal minded people (Permu 1969:6).

In an attempt to explain the objectives of religious polarisation, Thursby (1975:11) avers that all religions that are either founded or unfounded by human experience progressively degenerate with time because of the effect of human wilfulness and religious self-interest. Instead, just as Swami Dayannand Saraswati assumed, all seekers of truth should actively pursue the regeneration of religion and society through his proposed program of religious renewal and social reform. The northern part of India pursues the regeneration of religion as seen in the case of the Hindu pilgrimage of Ayodhya. The importance of religious activities is echoed in the several attempts by Hindus' to reclaim the sacred site of the ancient temple that is claimed to be the birthplace of their god Rama; a site that was taken by Muslims, replacing it with a mosque. The site has become a place of worship for Hindus, prayers for Muslims and has turned out to be the symbolic focus of Hindu-Muslims in India (Veer 1994:2-10). There is no doubt that northern India is the home of religions and religious saints that are venerated, and are centres of pilgrimage. The sacred centres are significant in the formation of religious communalism in India, and the formation of Hindu and Muslim nationalism (Veer 1994:11). Realistically, it sounds affirmative that both Hindus and Muslims in India have their distinct religious identities, whilst in some aspects the religious similarities in the Kashmir region are mirrored in syncretic mysticism, communalism, nationalism, and fundamentalism.

\section{Religious implication}

Historically, the contact that Kashmir had with the Greeks, Romans and the Persians led to its civilisation and acculturation. It also influenced the people's beliefs and worldviews as practically demonstrated by the Kashmiri's substitution of the earliest form of Naga worship with Brahmanism without experiencing any persecution (Bamzai 1994:16). There seem to be clear shreds of evidence recorded of the influence of Hinduism on Islam with the striking example of the Sadiq Nihang shrine, in the Jhang district of Punjab province. A lot of the Hindu practices were retained by the faqirs in charge of such shrines. Such as, the tradition of the superior disciple succeeding the faqir and remaining celibate, which is contrary to the practice at other Muhammadan shrines, where primogeniture is the custom. Also, the practice of a fire kept burning day and night and a loaf of bread being cooked annually in the same fire and shared with all those present. All these were Hindu customs and without doubt, Muslim orthodoxy of the primogeniture. A similar influence is exemplified in the case of Baba Ratan, a Hindu Yogi who has been included in the Muhammadan calendar of saints with a shrine in Bhatinda, in the Patiala district (Hastings et al. 1908). Historically, the successions of different eras in the Kashmir region had a great influence on the religious life and activities of the people. It became obvious that religion was used unequivocally to support the nationalist movement to become antagonistic and replace the colonial regimes and those perceived as invaders. This was aimed at reawakening the pride of India and its religious heritage (Smith 1971:96).

The enthusiasm for religious resurgence resulted in various forms of contrition and religious polemics, as seen in the case of Swami Dayannand whose criticisms exposed religious dissimilarities between Hindus and Muslims. $\mathrm{He}$ claims to have examined the content of the Qur'an bit by bit and concludes the following: firstly, God is presented with unworthy attributes that are not worthy of human worship. Secondly, God is portrayed as unjust and he encourages sin. Thirdly, Qur'an leads to immoral religious life and supports cruelty and licentiousness. Finally, Muhammad's portrayal in the Qur'an questions his prophetic claim and the Qur'an is not a revealed scripture, but a book made for selfish human interest (Thursby 1975:13). His zeal for the revealed aspect is expressed in his polemic approach as he juxtaposes Islam to Vedic faith, a religion he claimed as a true religion. This action was a premeditated missional approach to invite Muslims to the Hindu fold. Hence, apologetics and polemics were used as a means of religious persuasion, which later turned to violent fundamentalism. This kind of approach was demonstrated by Pandit Lekh Ram, a disciple of Dayannand who organised a system of paid polemic preachers to focus their mission on the proselytisation of Muslims, and that resulted in religious controversy, violence and his assassination by a Muslim in 1897 (Thursby 1975:14-15). This creates the impression that religious influences led to the conversion of both Muslims and Hindus, which sparked persecutions along communal and political lines. Thursby (1975:18) succinctly avers, 'Controversialist exchanges were a contributing cause of inter-religious violence which in turn became a motive for mass mobilisation on a communal basis in northern India'.

Furthermore, religious discord is ignited by religious fundamentalism and it can lead to the politics of antagonism which leads to the use of religious resources to defend religious ethos. When the political and social situation of a religiously pluralistic context is triggered, the root cause may be embedded in the sacred text, values and worldviews. Therefore, religious fundamentalism seems to be the aggressive packages of meaningful and compelling worldviews that are zealously heaped onto communities armed with religious convictions to shape the world (Clarke 2017:159). The region of Kashmir attached great significance to religion and despite the political and socio-economic problems faced by them, could not rule out the influence of religious communalism and fundamentalism. Zeroing in on religion does not disprove the frameworks of politics, culture, socio-economic and psychological enthusiasm that undergird fundamentalism. Instead, the religious sources and systems that triggered fundamentalism should be acknowledged and the religious potentials to combat fundamentalists and their derivatives should be applied (Clarke 2017:165). 


\section{Conclusion}

The beauty and the religiosity of Kashmir and Kashmiris as depicted by ancient historians and writers of Indian history are so fascinating. The region has layers of religious antiquities and history built one upon the other by successive eras and dynasties of different rulers. In each era, there seems to have been a focus on political power, religious communalism, economic exploitation and social reform. All these appear to be girded with religious values and worldviews that were shaped by their worldly realities. Hindus and Muslims in the region of Kashmir and northern India once lived in a religiously pluralistic context, tolerating one another until the realities of political power play and socio-economic sentiments began to manifest along religious lines. These problems fuelled by the partition in 1947 and a series of wars and violent confrontations, escalated the tension in Hindu-Muslim relations and led to religious nationalism and fundamentalism. The Kashmir that was once known for its religious pluralism and tolerance has turned to be a place of sectarian divide, religious nationalism and fundamentalism (Patterson 2013:7). The valley of Kashmir that was renowned for its geographical beauty with mountains, valleys, pure streams, fresh air and a hospitable valley (Chaudhary 2013:3) now functions as the lodgements and fortresses for conflicts (Clarke 2017:184). The India that is known as the mother of religions cannot relegate the primary role of religion in their political and socio-economic affairs. Therefore, it is right to acknowledge politico-religious and socio-economic factors in the present state of Kashmir. And, it will not be wrong to affirm that religion plays a key role in the conflict between Hindus and Muslims in Kashmir.

\section{Acknowledgements}

\section{Competing interests}

The authors have declared that no competing interests exist.

\section{Authors' contribution}

I declare that I am the sole author of this research article.

\section{Ethical considerations}

This article followed all ethical standards for a research without direct contact with human or animal subjects.

\section{Funding information}

This research received no specific grant from any funding agency in the public, commercial or not-for-profit sectors.

\section{Data availability}

Data sharing is not applicable to this article as no new data were created or analysed during this study.

\section{Disclaimer}

The views and opinions expressed in this article are those of the authors and do not necessarily reflect the official policy or position of any affiliated agency of the authors.

\section{References}

Augustyn, A., Bauer, P., Duignan, B., Eldridge, A., Gregersen, E., McKenna, A. et al. (eds.), 2019, 'Kashmir: Region, Indian subcontinent, Asia', Encyclopædia Britannica, 31 October 2019, viewed 20 April 2020, from https://www.britannica. $\mathrm{com} /$ place/Kashmir-region-Indian-subcontinent.

Bakshi, S.R., 1997, Kashmir: History and people, Sarup \& Sons, New Delhi.

Bamzai, P.N.K., 1994, Culture and political history of Kashmir, 1st edn., M D Publications, New Delhi.

Chaudhary, N.M., 2013, Saga of Kashmir: Kashmir of my stories, 1st edn., Partridge Publishing, Partridge, New Delhi.

Clarke, S., 2017, Competing fundamentalisms: Violent extremism in Christianity, Islam, and Hinduism, Westminster John Knox Press, Louisville, KY.

Davis, R.H., 1995, 'A brief history of religions in India', in D.S. Lopez Jr., (ed.), Religions of India in practice, pp. 3-52, Princeton University Press, Princeton, NJ.

Eliot, C., 1962, Hinduism and Buddhism: An historical sketch, Barnes and Noble, New York, NY.

Ellis-Peterson, H., 2020, 'Inside Delhi: Beaten, lynched and burnt alive', The Guardian, 01 March 2020, viewed 10 March 2020, from https://www.theguardian.com/ world/2020/mar/01/india-delhi-after-hindu-mob-riot-religious-hatrednationalists.

Engineer, A.A., 1999, 'Muslim views of Hindu since 1950', in J. Waardenburg (ed.), Muslim perceptions of other religions: A historical survey, pp. 263-269, Oxford University Press, New York, NY.

Flood, G., 2003, 'Introduction: Establishing the boundaries', in G. Flood (ed.), The Blackwell companion to Hinduism, pp. 1-19, Blackwell Pub., Malden, $\mathrm{MA}$

Frost, J.W., 2004, A history of Christian, Jewish, Hindu, Buddhist, and Muslim perspectives on war and peace, vol. 65, Edwin Mellen Press, Lewiston, NY.

Gold, A.G., Smith, B.K., Dimock, E.C., Doniger, W., Basham, A.L., Narayanan, V. et al. (eds.), 2019, 'Hinduism', Encyclopædia Britannica, 14 August 2019, viewed 19 April 2020, from https://www.britannica.com/topic/Hinduism.

Hackett, C., 2015, 'By 2050, India to have world's largest populations of Hindus and Muslims', Research Pew Centre, 21 April 2015, viewed 12 March 2020, from https://www. pewresearch.org/fact-tank/2015/04/21/by-2050-india-to-haveworlds-largest-populations-of-hindus-and-muslims/.

Hastings, J., Selbie, J.A. \& Gray, L.H., 1908, Encyclopaedia of religion and ethics, T \& T Clark, Logos Bible Software, Edinburgh.

Jammu \& Kashmir Tourism Development Corporation, n.d., Religions in Kashmir, viewed 10 March 2020, from https://www.jktdc.co.in/Religions-in-Kashmir. aspx.

Jones, K.W., 1968, 'Communalism in the Punjab: The Arya Samaj contribution', Journa of Asian Studies 28(1), 39-54. https://doi.org/10.2307/2942838

Malik, V., 2018, Kashmir the story, directed by V. Malik, Times Network, Episodes 1-6, viewed 20 March 2020, from Amazon Prime.

Metcalf, B.D. \& Metcalf, T.R., 2006, A concise history of modern India, 2nd edn., Cambridge University Press, New York, NY.

Metzger, W., 2012, Tell the truth: The whole Gospel wholly by grace communicated truthfully and lovingly: An Evangelism training manual for group and individua use, 4th edn., IVP Books, Downers Grove, IL.

Misri, S.S. \& Misri, S.G., 2016, Kashmir - A concise history: Mahabharata Epoch 3067 $B C E$ to Modi Era 2016 AD., 1st edn., Independently Published, India.

Nielsen, N.C., 1993, Fundamentalism, mythos, and world religions, University of New York Press, Albany, NY.

Office of the Registrar \& Census Commissioner (n.d.), Religion, viewed 15 October 2020, from https://censusindia.gov.in/Census_And_You/religion.aspx.

Patterson, E., 2013, Kashmir: Religious diversity becomes religious militancy Georgetown University, Washington, DC.

Permu, R.K., 1969, A history of Muslim rule in Kashmir 1320-1819, People's Publishing House, New Delhi.

Pillalamarri, A., 2019, 'The origins of Hindu-Muslim conflict in South Asia: What are the historical origins of animosities between South Asia's two largest religions', The Diplomat, 16 August 2019, viewed 06 May 2020, from https://thediplomat. com/2019/03/the-origins-of-hindu-muslim-conflict-in-south-asia/.

Qureshi, I.H., 1955, 'Relations between the Hindus and the Muslims in the subcontinent of India and Pakistan / Les Relations Entre Les Indous Et Les Musulmans Dans Le Sous-Continent De L'inde Et Du Pakistan', Civilizations 5(1), 43-53, viewed 17 April 2020, from www.jstor.org/stable/41230004.

Renou, L., 1961, Hinduism. Great religions of modern man, G. Braziller, New York, NY. Smith, D.E., 1970, Religion and political development, an analytic study, Little, Brown, Boston, MA.

Smith, D.E., 1971, Religion, politics, and social change in the third world: A sourcebook, Free Press, New York, NY

Smith, W.C., 1957, Islam in modern history, Princeton University Press, Princeton, NJ.

Stein, M.A., 1989, Kalhana's Rājataranginịi: A chronicle of the Kings of Kaśmīr, vol. 2, bk. 8, Motilal Banarsidass, Delhi.

Stein, M.A., 1900, Kalhana's Rajatarangini: A chronicle of the Kings of Kasmir, vol. 1, Motilal Banarsidass, New Delhi. 
Talbot, C., 1995, 'Inscribing the other, inscribing the self: Hindu-Muslim identities in precolonial India', Comparative Studies in Society and History 37(4), 692-722. https://doi.org/10.1017/S0010417500019927

Thursby, G.R., 1975, Hindu-Muslim relations in British India: A study of controversy, conflict, and communal movements in Northern India 1923-1928, Leiden, Brill.

Veer, P.V., 1994, Religious nationalism: Hindus and Muslims in India, University of California Press, Berkeley, CA.

Wakefield, W., 1879, The Happy Valley, sketches of Kashmir and the Kashmiris, Sampson Low, London.
Werner, K., 1994, A popular dictionary of Hinduism, Curzon, Richmond.

Wilsey, J.D., 2015, American exceptionalism and civil religion: Reassessing the history of an idea, IVP Academic, an imprint of InterVarsity Press, Downers Grove, IL.

Wilson, H.H., 1960, Hindu history of Kashmir, Susil Gupta, Calcutta.

Young, R.F., 2014, 'Hinduism: History, beliefs, practices', in T.C. Muck, H.A. Netland \& G.R. McDermott (eds.), Handbook of religion: A Christian engagement with traditions, teachings, and practices, pp. 49-55, Baker Academic, Grand Rapids, MI. Younghusband, F., 1909, Kashmir, British Library, London. 